\title{
Syngas Production From Palm Kernel Shells With Enhanced Tar Removal Using Biochar From Agricultural Residues ${ }^{\dagger}$
}

\author{
Wipawee Dechapanya ${ }^{1}$, Suttipong Rattanahirun ${ }^{2}$ and Attaso Khamwichit ${ }^{1 *}$ \\ ${ }^{1}$ Department of Chemical Engineering, Walailak University, Nakhon Si Thammarat, Thailand, ${ }^{2}$ Department of Civil \\ and Environmental Engineering, Walailak University, Nakhon Si Thammarat, Thailand
}

OPEN ACCESS

Edited by:

Bernard Saw,

Tunku Abdul Rahman University,

Malaysia

Reviewed by:

Rock Keey Liew

Universiti Malaysia Terengganu,

Malaysia

Nor Adilla Rashidi,

University of Technology Petronas,

Malaysia

*Correspondence:

Attaso Khamwichit

kattaso@mail.wu.ac.th

${ }^{\dagger}$ This paper is an extended and revised article presented at the International Conference on

Sustainable Energy and Green Technology 2019 (SEGT 2019) on 11-14 December 2019 in Bangkok,

Thailand.

Specialty section: This article was submitted to Sustainable Energy Systems and Policies,

a section of the journa

Frontiers in Energy Research

Received: 21 April 2020

Accepted: 23 June 2020

Published: 28 July 2020

Citation:

Dechapanya W, Rattanahirun S and Khamwichit A (2020) Syngas

Production From Palm Kernel Shells With Enhanced Tar Removal Using

Biochar From Agricultural Residues.

Front. Energy Res. 8:157.

doi: 10.3389/fenrg.2020.00157
In this study, palm kernel shells (PKS) were utilized in an air gasification process to produce syngas. Also, biochar prepared from pyrolysis of the mangosteen and durian peels was used in the process to enhance the tar removal efficiency. The expected outcomes of this study could result in not only the generation of renewable energy but also the waste utilization of agricultural residues. The effect of catalysts and biochar on tar reduction to improve the syngas quality were extensively studied. A downdraft gasifier equipped with catalytic and adsorption units was utilized to produce syngas. The process was operated with $1 \mathrm{~kg}$ of palm shell per batch at a fixed airflow rate of $25 \mathrm{~L} / \mathrm{min}$. The $\mathrm{NiO} / \mathrm{CaO}$ catalysts with a fixed $\mathrm{CaO}$ amount of $10 \mathrm{wt} \%$ and various $\mathrm{NiO}$ contents of 2, 4, and $8 \mathrm{wt} \%$ were synthesized by co-impregnation on the ceramic supporter. The results of SEM analysis showed that the $\mathrm{NiO}$ and $\mathrm{CaO}$ were deposited and well dispersed on the porous ceramic supporters. The presence of an associated active $\mathrm{NiO}$ peak at a wavelength of $692 \mathrm{~cm}^{-1}$ was observed in the FTIR result. The durian and mangosteen peels residues were pyrolyzed at $400-600^{\circ} \mathrm{C}$ for $2 \mathrm{~h}$ to prepare biochar to be used as tar adsorbent. The BET surface area of obtained biochar was $0.9219-0.9989 \mathrm{~m}^{2} / \mathrm{g}$ with a range of adsorption pore size of $11.193-11.912 \mathrm{~nm}$. The syngas samples were collected from the gasification unit at 15, 25, 35, 45, and 60 min during a 1-h period of processing time. The syngas compositions were analyzed by gas chromatography. The $\mathrm{GC}$ results indicated that increasing $\mathrm{NiO}$ contents in the catalysts tended to result in increasing methane and carbon dioxide concentration of the syngas, possibly contributed from the tar cracking reactions. With the presence of biochar, the amount of tar captured in the filter unit was significantly increased up to nine times compared to the system without biochar.

Keywords: gasification, syngas improvement, palm kernel shells, biomass, biochar, tar adsorption

\section{INTRODUCTION}

Thailand is an important food-production country with abundant plantation areas to produce agricultural products. In southern Thailand, the palm-oil industry has been growing for decades. The government policy on increasing usages and production of renewable energy from high potential sources to overcome fossil energy crises has been one of the driving forces to promote 
planting of oil palm. In 2018, the Office of Agricultural Economics of Thailand (OAE) estimated the plantation area of oil palm agriculture to be roughly 2 million acres, yielding almost 16.8 million tons of oil palm crops to feed the refinery plants for palm oil production (Office of Agricultural Economics [OAE], 2019). Consumption for industrial uses leads to a massive amount of biomass residues left from agricultural activities and the refinery process. Typically, biomass residues from palm oil refinery process are approximately 78 to 82 percent, mainly composed of empty fruit bunch, fibers, and kernel shells. These biomass residues can be potentially used as feedstocks in thermochemical processes to produce biofuels or syngas (Lam et al., 2019). The syngas obtained from a biomass gasification process commonly consists of combustible components with high heat value that can be used as an alternative source of fuel for the direct heating or gas engines in power generation processes. Typically, the properties of the produced syngas depend on several affecting factors such as the type of biomass, setup and process details, and operating conditions. Besides palm kernel shell, many other types of biomass, including risk husk, coconut shells, cedarwood, and almond residues, have been demonstrated to be used as raw materials in some kinds of gasification to produce useful syngas as well (Chaiprasert and Vitidsant, 2009; Li et al., 2010; Koike et al., 2013; McCaffrey et al., 2019). However, one typical problem often found in such applications is the coagulation due to the deposition of condensed tar generated from the gasification process in the fuel line and engine. Consequently, these tar components result in less efficiency and internal damage to the engine. There are several approaches to remove tar from the produced syngas. Several studies showed that additional thermal cracking reactions of the hot syngas with the aid of steam or catalysts could significantly decrease the tar components from syngas (Bonilla et al., 2019). The process involves chemical reactions to transform tar components into high heating value gaseous components, such as oxygen/sulfur-containing hydrocarbon, aromatic compounds, and polynuclear aromatic hydrocarbons (PAHs) (Kostyniuk et al., 2019). The decomposition of tar involves complex reaction pathways associated with the presence of hydrocarbon compounds. Those reactions include partial oxidation, dry reforming, steam reforming, hydrogenation, thermal cracking, and carbon formation, which generally result in the formation of hydrogen, methane, carbon monoxide, and carbon dioxide as the end product species.

Several research works have suggested the uses of nickel or base oxides in the gasification process to improve the quality of syngas (Mohammed et al., 2011; Wang et al., 2012). A study by Sutton et al. (2001) reported that nickel oxide (NiO) effectively enhances tar cracking and hydrocarbon removal of the syngas, particularly at temperatures higher than $780^{\circ} \mathrm{C}$. Catalyst promoters, such as $\mathrm{CeO}_{2}$ (Kimura et al., 2006), manganese oxides $\left(\mathrm{MnO}_{\mathrm{x}}\right)$ (Koike et al., 2013), and metallic Pt or Co (Chaiprasert and Vitidsant, 2009), could be incorporated into the nickel-based catalysts to facilitate further involving watergas shift reforming reactions, resulting in increasing syngas yield with higher hydrogen content. For more economical approaches, other lower-cost but less effective oxides such as $\mathrm{CaO}$ or $\mathrm{MgO}$ could be used and incorporated into the process and still give acceptable gas yield results (Kong et al., 2011; Ismail et al., 2012). Many studies have also found the influence of $\mathrm{CaO}$ on promoting the reaction rate of partial oxidation and the water-gas shift reaction to enhance the $\mathrm{H}_{2}$ throughput of the gasification process (Han et al., 2011; Chiang et al., 2012; Udomsirichakorn et al., 2013). As suggested from the literature reviews mentioned above, the implementation of combined $\mathrm{NiO}$ and $\mathrm{CaO}$ catalysts could synergistically improve the performance of the gasification process of the preferred choice of biomass, particularly in terms of high gas yields with low tar components. In addition, several materials, including wood chips, activated carbon, rice husk char, and corncob biochar, have demonstrated the capacity of adsorbing tar components from syngas produced by various gasification conditions to some extent due to their porous surfaces (Kong et al., 2011). The effect of functional groups of the adsorbent could also play an essential role in the adsorption mechanism of the tar species, particularly on the phenolic contents (Brandt et al., 2000; Li et al., 2010). Besides the type of adsorbent, the operating temperature of the adsorption unit, preferable below $250^{\circ} \mathrm{C}$, also affects the tar reduction performance (Ravenni et al., 2019).

The purpose of this research was to study the effects of $\mathrm{NiO} / \mathrm{CaO}$-based catalysts and biochar obtained from agricultural biomass residues on the syngas's quality improvement from the gasification process of palm kernels. Using the co-impregnation sol-gel method, $\mathrm{NiO}$ and $\mathrm{CaO}$ were doped onto the ceramic supports. The concentration of $\mathrm{NiO}$ was varied into three different dosages of 2, 4 , and $8 \mathrm{wt} \%$, whereas the $\mathrm{CaO}$ content was fixed at $10 \mathrm{wt} \%$. To enhance the tar reduction, biochar, which was prepared from pyrolysis of durian and mangosteen peel residues, was utilized to adsorb excess liquid and gaseous tar from the produced syngas.

\section{MATERIALS AND METHODS}

\section{Catalyst Preparation}

Nickel nitrate hexahydrate $\left(\mathrm{Ni}\left[\mathrm{NO}_{3}\right]_{2} \cdot 6 \mathrm{H}_{2} \mathrm{O}\right)$, AR grade purchased from Ajax Finechem, and calcium nitrate $\left(\mathrm{Ca}\left[\mathrm{NO}_{3}\right]_{2} \cdot 4 \mathrm{H}_{2} \mathrm{O}\right)$, AR grade obtained from Loba Chemie, were used as the precursors to prepare the solutions with three different weight ratios of $1: 5,2: 5$, and $4: 5$. Then the ceramic-ring supporters with the high surface area were soaked in precursor solutions in the hot basin at $70^{\circ} \mathrm{C}$ until the gel solution was completely dried. The wet substrates were heated in the oven at $110^{\circ} \mathrm{C}$ for $24 \mathrm{~h}$ before calcining at $950^{\circ} \mathrm{C}$ for $6 \mathrm{~h}$ before being kept in the desiccator at room temperature.

\section{Biochar Preparation}

Durian and Mangosteen peels were sun-dried and chopped to be approximately $2 \mathrm{~cm}$ in diameter before putting into $18 \mathrm{~L}$ of a bucket. The bucket filled with the dried and chopped biomass was placed along with woodchips and palm fiber (used as fuel for the synthesis of biochar) into a $100 \mathrm{~L}$ Stainless Steel tank. The pyrolysis process of biochar was conducted at $400-600^{\circ} \mathrm{C}$ for $2 \mathrm{~h}$. 


\section{Experimental Setup of the Gasification Process}

Palm kernel shell was dried in the oven at $80^{\circ} \mathrm{C}$ for $24 \mathrm{~h}$ prior to being placed in the gasifier with the amount of $1 \mathrm{~kg}$. Air was pumped at a constant rate of $25 \mathrm{~L} / \mathrm{min}$ to the gasifier to maintain biomass to air equivalent ratio of 1:0.6. The process is comprised of a downdraft gasifier, catalytic reactor, tar condenser, and tar filter. The synthesized ceramic ring doped with catalyst was filled in the catalytic reactor with the ratio of PKS/catalyst of 1:0.25. Cracked tar from the catalytic reactor was then condensed in the tar condenser. Syngas was passed to the tar filter unit, packed with $1 \mathrm{~kg}$ of biochar (the amount ratio of palm kernels to biochar of 1:1), for the adsorption of gaseous tar. Figure 1 illustrates the gasification process diagram used in this study.

\section{Characterization}

\section{Composition and Heating Value Analysis}

Compositions of biomass (kernel shell) and synthesized biochar from durian and mangosteen peels in this study were analyzed according to ASTMD3172-3175 standard. Thermo Quest model Flash EA 1112 was used to analyze elemental compositions of both biomass and biochar. The heating value of the kernel shell was analyzed using a Bomb calorimeter model AC 500.

\section{Morphology}

Morphological properties of biomass, biochar, and catalyst were examined by Scanning Electron Microscope (SEM, Model Merlin compact, Zeiss). The specimens were mounted on aluminum stubs, sputter-coated with gold, and examined in a Merlin compact scanning electron microscope. The prepared samples were analyzed at $1,000 \times$ and $10,000 \times$ magnifications.

\section{BET Analysis}

Specific surface areas and pore diameters of the synthesized biochar were analyzed using the Brunauer-Emmett-Teller (BET) technique (Surface Area and Porosity Analyzer [BET], ASAP2460, Micromeritics, United States).

\section{FTIR Analysis}

Functional groups of chemical structures of the doped ceramic ring were analyzed by ATR-FTIR Spectrometer (Model Tensor 27, Bruker) using the ATR-FTIR technique.

\section{Syngas Analysis}

Syngas produced from the gasification process of kernel shell was collected at the sampling point of the tar filter unit at 15, 25, 35, 45, and $60 \mathrm{~min}$. Gas samples were collected into Tedlar bags and then were analyzed by Gas Chromatography model 7890B.

\section{RESULTS AND DISCUSSION}

\section{Proximate and Ultimate Analysis of PKS}

The results of the proximate and ultimate analysis of the palm kernels used in this study are shown in Table 1. The volatile matter concentration was found to be approximately $71.6 \%$, whereas the fixed carbon and moisture contents were 15.1 and $9.9 \%$, respectively. Since the kernels contained a high amount of volatile matter, the material can be potentially combusted in the gasification process to generate energy. The $\mathrm{CHN}-\mathrm{O}$ elemental

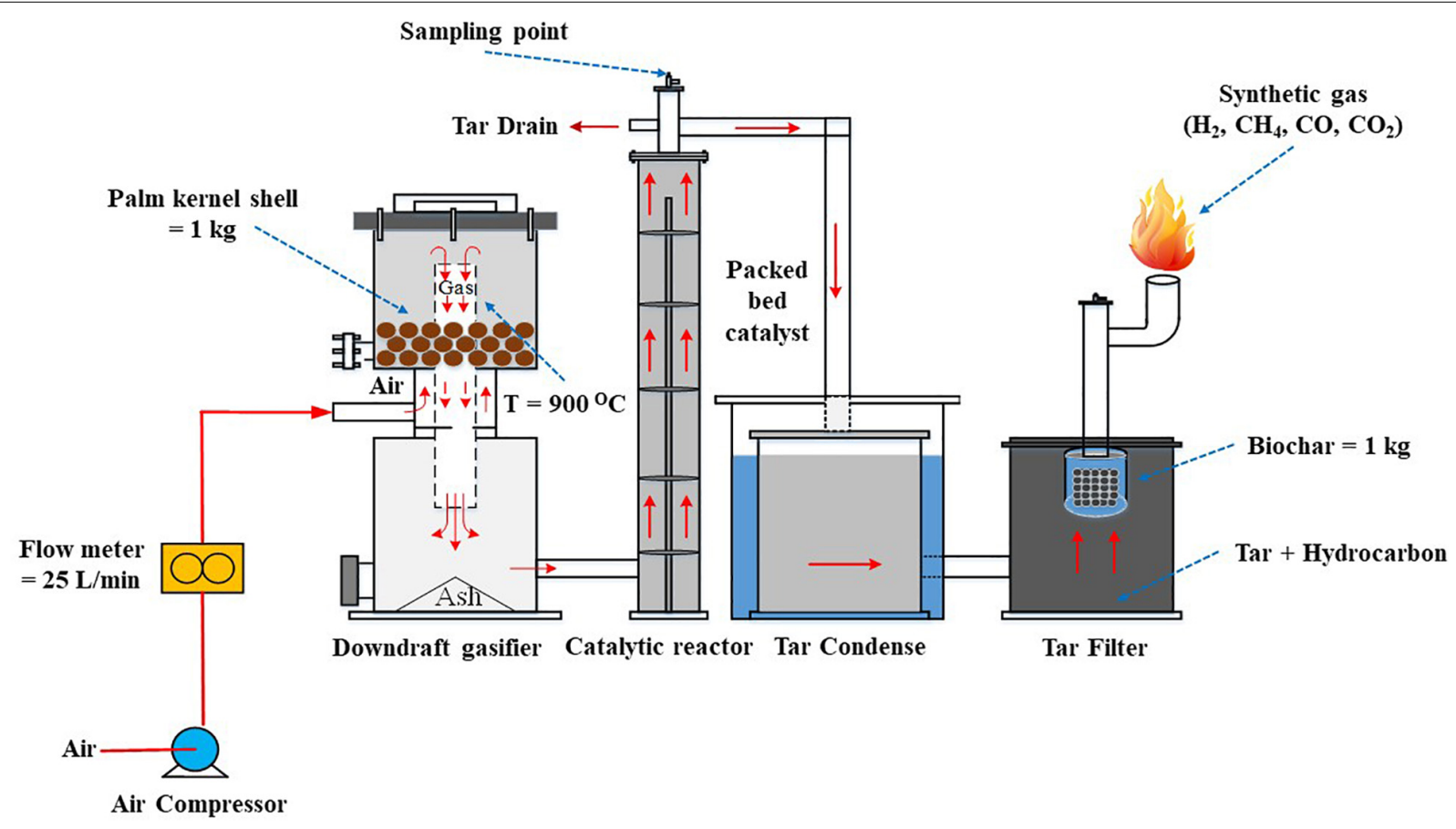

FIGURE 1 | Schematic illustration of the gasification process. 
TABLE 1 | Proximate and ultimate analysis results for the palm kernels.

\begin{tabular}{|c|c|c|c|c|c|c|c|c|c|}
\hline \multicolumn{4}{|c|}{ Proximate analysis (wt\% dry basis) } & \multicolumn{5}{|c|}{ Ultimate analysis (wt\% dry basis) } & \multirow[t]{2}{*}{ References } \\
\hline Moisture content & Ash & Volatile matter & Fixed carbon & C & $\mathbf{H}$ & 0 & $\mathbf{N}$ & $\mathbf{S}$ & \\
\hline 9.94 & 3.41 & 71.57 & 15.08 & 52.30 & 7.83 & 39.17 & 0.42 & 0.28 & This study \\
\hline 2.62 & 1.82 & 71.53 & 24.03 & 49.10 & 6.37 & 43.35 & 0.6 & 0.58 & Rashidi and Yusup, 2019 \\
\hline 5.69 & 1.72 & 69.10 & 23.49 & 46.92 & 8.95 & 40.63 & 1.15 & 2.35 & Ogunkanmi et al., 2018 \\
\hline 6.33 & 11.75 & 62.82 & 19.10 & 44.29 & 9.01 & 43.13 & 2.37 & 1.20 & Ahmad et al., 2014 \\
\hline
\end{tabular}

analysis indicated that the combustible kernels consisted of carbon, hydrogen, and oxygen, which were suitable to be used as biomass raw material for the purposed gasification. As shown in Table 2, high heating value (HHV) and low heating value (LHV) of the shell obtained from Bomb calorimeter measurement were roughly 4,830 and $4,225 \mathrm{kcal} / \mathrm{kg}$, respectively. In general, the results were in good agreement with past related research studies reported elsewhere in which the biomass materials were successfully utilized to produce syngas.

\section{Structure and Morphology of the Catalysts}

Morphology of the prepared catalysts containing $\mathrm{NiO}$ and $\mathrm{CaO}$ on ceramic supporter was analyzed from the SEM results. Figure 2 illustrates the SEM pictures of the (a) Ceramic supporter, (b) $\mathrm{NiO}(2 \mathrm{wt} \%) / \mathrm{CaO}(10 \mathrm{wt} \%) /$ Ceramic ring, (c) $\mathrm{NiO}(4$ wt $\%) / \mathrm{CaO}(10 \mathrm{wt} \%) /$ Ceramic ring, and (d) $\mathrm{NiO}(8 \mathrm{wt} \%) / \mathrm{CaO}$ (10 wt\%)/Ceramic ring catalysts at a magnification around $1,000 \times$ magnifications. The micrographs exhibit rough surface with uniform distribution of the $\mathrm{NiO} / \mathrm{CaO}$ catalyst crystals on the porous supporter. At fixed $10 \mathrm{wt} \% \mathrm{CaO}$, the size of the disperse agglomerates tended to increase with increasing coimpregnated $\mathrm{NiO}$ contents.

The $\mathrm{NiO}$ and $\mathrm{CaO}$ contents were evaluated from the element analysis of the EDX results. Figure 3 shows the EDX results of the prepared $\mathrm{NiO}(\mathrm{x} \%) / \mathrm{CaO}(10 \%) /$ Ceramic catalysts with varied $\mathrm{NiO}$ contents of $2 \mathrm{wt} \%, 4 \mathrm{wt} \%$, and $8 \mathrm{wt} \%$. The EDX analysis suggested that active $\mathrm{NiO}$ and $\mathrm{CaO}$ were successfully co-impregnated. The catalysts contained $\mathrm{Ni}$ and $\mathrm{Ca}$ contents relatively close to the prepared solution concentrations. The increase in the concentration of $\mathrm{Ni}\left(\mathrm{NO}_{3}\right)_{2} \cdot 6 \mathrm{H}_{2} \mathrm{O}$ in the solution generally increased the $\mathrm{Ni}$ content in the catalyst. The Ni compositions were found to be $2.9 \%$ for the $\mathrm{NiO}(2 \%) / \mathrm{CaO}(10 \%), 6.9 \%$ for the $\mathrm{NiO}(4 \%) / \mathrm{CaO}(10 \%)$, and $10.9 \%$ for the $\mathrm{NiO}(2 \%) / \mathrm{CaO}(10 \%)$, respectively. The presence of $\mathrm{NiO}$ and $\mathrm{CaO}$ deposited on the ceramic surface, as seen from

TABLE 2 | Heating values of palm kernels.

\begin{tabular}{lcc}
\hline HHV (kcal/kg) & LHV (kcal/kg) & References \\
\hline $4,830.70$ & $4,225.39$ & This study \\
$4,512.13$ & $3,996.46$ & Phanpruk and Khamwichit, 2017 \\
$5,469.57$ & $5,812.96$ & Okoroigwe and Saffron, 2012 \\
$4,497.98$ & N/A & Shahbaz et al., 2016 \\
$3,857.46$ & & Samiran et al., 2015
\end{tabular}

the EDX results, was the indicator of effective impregnation of the active compounds. This could be attributed to the interaction between $\mathrm{NiO} / \mathrm{CaO}$ and the silicate oxide $\left(\mathrm{SiO}_{2}\right)$ component of the ceramic supporter, as suggested in Wang's study (Wang et al., 2012). In addition, the presence of active $\mathrm{NiO}$ on the catalyst was also confirmed in the FTIR result, where the peak at the wavelength of $692 \mathrm{~cm}^{-1}$ associated with $\mathrm{Ni}-\mathrm{O}$ stretching vibration band was observed (Segawa et al., 2015), as shown in Figure 4. The specific surface area of the prepared $\mathrm{NiO} / \mathrm{CaO}$ catalysts with $8 \% \mathrm{NiO}$ obtained from BET analysis was found to be $6.192 \mathrm{~m}^{2} / \mathrm{g}$ with an average pore size of $14.48 \mathrm{~nm}$.

\section{Biochar Properties}

Biochar, synthesized from durian and mangosteen peel residues, was used as the physical absorbent for tar removal in this study at a fixed ratio of 50:50 by weight of durian and mangosteen. Figure 5 illustrates the SEM results of biochar at $10 \mathrm{kV}$ with a magnification of $500 \times$ and $1,000 \times$ times. The SEM pictures of the sectional fracture surface of both durian and mangosteen show porous structures with various pore sizes across. The results showed that the pore size distribution of the biochar made from durian peels appeared to be more uniform than those obtained from mangosteen. Biochar from mangosteen possessed a porous structure with broader pore size distribution across the surface. The SEM results were in good with BET surface analysis.

The EDX analysis indicated the main elemental compositions of the prepared biochar, as shown in Figure 6. The biochar obtained from durian peels consisted of $75 \% \mathrm{C}, 12.5 \% \mathrm{O}, 11.3 \%$ $\mathrm{K}$, and $1.1 \% \mathrm{Mg}$, respectively. The elemental composition results were typical for biochar, which could be used as an adsorbent to physically adsorb tar compounds from syngas in the gasification process (Chaichana et al., 2014).

The specific surface areas (SSF) were found to be $0.9989 \mathrm{~m}^{2} / \mathrm{g}$ for the durian-peel biochar, and $0.9219 \mathrm{~m}^{2} / \mathrm{g}$ for the mangosteenpeel biochar. In addition, the average pore diameter of the durianpeel biochar $(11.193 \mathrm{~nm})$ was relatively smaller than that of the mangosteen-peel biochar $(11.912 \mathrm{~nm})$. It was believed that the mixture of 50:50 ratio between the materials would be capable of adsorbing condensed volatile tar residues with a wide spectrum of molecular sizes. The gasification performance study will be further discussed.

\section{Effects of the Catalyst on Gasification Performance}

In the air down-draft gasifier, the palm kernel shells were fed in at the top and gradually consumed their way downwards 

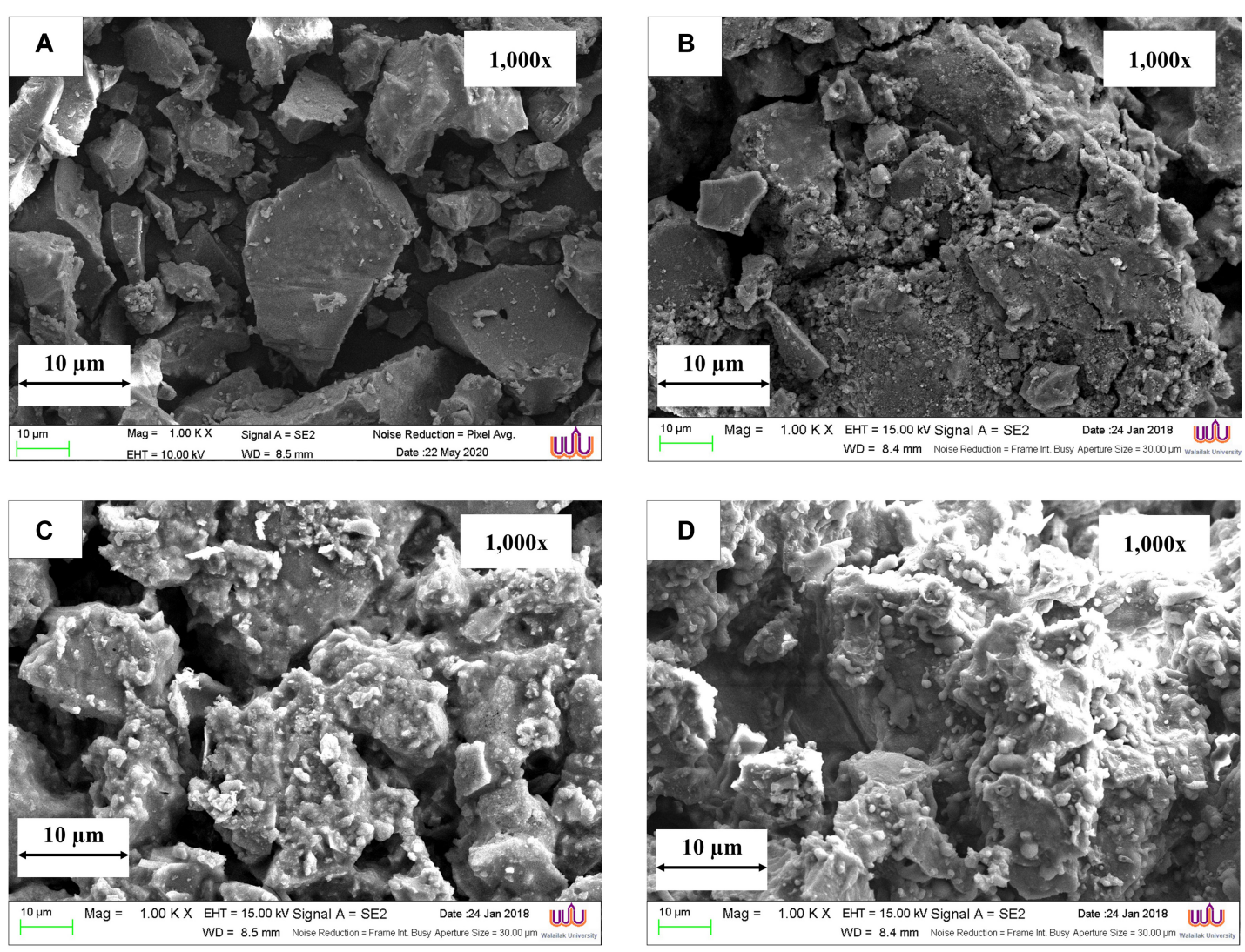

FIGURE 2 | SEM results at $15 \mathrm{kV}$ (1,000 × magnifications) of (A) Ceramic supporter, (B) 2\%NiO/10\%CaO/Ceramic, (C) 4\% NiO/10\%CaO/Ceramic, and (D) $8 \% \mathrm{NiO} / 10 \% \mathrm{CaO} /$ Ceramic.

through the gasifier. The biomass was first dried and then pyrolyzed due to the heat emanating from the hotter zones below. Subsequently, tar and char components were partially oxidized in the combustion and reduction zones, releasing heat and raising the temperature to roughly $500^{\circ} \mathrm{C}$. The remaining carbon could react with carbon dioxide and water to yield carbon monoxide and hydrogen. Meanwhile, the produced $\mathrm{CO}, \mathrm{CO}_{2}$, $\mathrm{H}_{2}$, and $\mathrm{CH}_{4}$ gas products could possibly react with carbon and hydrocarbon gases to some extent. The hot gas then entered the catalytic reactor containing the prepared $\mathrm{NiO} / \mathrm{CaO}$ catalysts, in which the tar having large molecules and high molecular weight was essentially converted into smaller gaseous compounds. The involving chemical reactions of the catalytic gasification process can be described in Eqs. (1)-(12) (Wang et al., 2012; Bonilla et al., 2019), as shown in the following:

$$
\mathrm{C}_{\mathrm{x}} \mathrm{H}_{\mathrm{y}} \mathrm{O}_{\mathrm{z}} \rightarrow \mathrm{aCO}_{2}+\mathrm{bCH}_{4}+\mathrm{cCO}+\mathrm{eH}_{2}+\mathrm{fC}_{2+}
$$

Char combustion:

$$
\begin{aligned}
\mathrm{C}_{2}+1 / 2 \mathrm{O}_{2} & \rightarrow \mathrm{C}+\mathrm{CO} \\
\mathrm{C}+\mathrm{O}_{2} & \rightarrow \mathrm{CO}_{2}
\end{aligned}
$$

Boudouard reaction:

$$
\mathrm{C}+\mathrm{CO}_{2} \rightarrow 2 \mathrm{CO}
$$

Primary water-gas reaction:

$$
\mathrm{C}+\mathrm{H}_{2} \mathrm{O} \rightarrow \mathrm{CO}+\mathrm{H}_{2}
$$

Homogenous gas-phase reactions:

$$
\begin{gathered}
\mathrm{C}+2 \mathrm{H}_{2} \rightarrow \mathrm{CH}_{4} \\
\mathrm{CO}+1 / 2 \mathrm{O}_{2} \rightarrow \mathrm{CO}_{2} \\
\mathrm{H}_{2}+1 / 2 \mathrm{O}_{2} \rightarrow \mathrm{H}_{2} \mathrm{O} \\
\mathrm{CH}_{4}+2 \mathrm{O}_{2} \rightarrow \mathrm{CO}_{2}+\mathrm{H}_{2} \mathrm{O}
\end{gathered}
$$

Water-gas shift reaction:

$$
\mathrm{CO}+\mathrm{H}_{2} \mathrm{O} \rightarrow \mathrm{CO}_{2}+\mathrm{H}_{2}
$$

Stream reforming methane reaction:

$$
\mathrm{CH}_{4}+\mathrm{H}_{2} \mathrm{O} \rightarrow \mathrm{CO}+3 \mathrm{H}_{2}
$$

Secondary tar cracking reaction:

$$
\mathrm{C}_{\mathrm{m}} \mathrm{H}_{\mathrm{n}}(\operatorname{tar})+\mathrm{gH}_{2} \mathrm{O} \rightarrow \mathrm{hCO}_{2}+\mathrm{iH}_{2}
$$

In this study, the gas chromatography (GC) results of the syngas samples, obtained from the air gasification process with fixed biomass to air ratio (ER) of 1:0.6 at 15, 25, 35, 45, and 


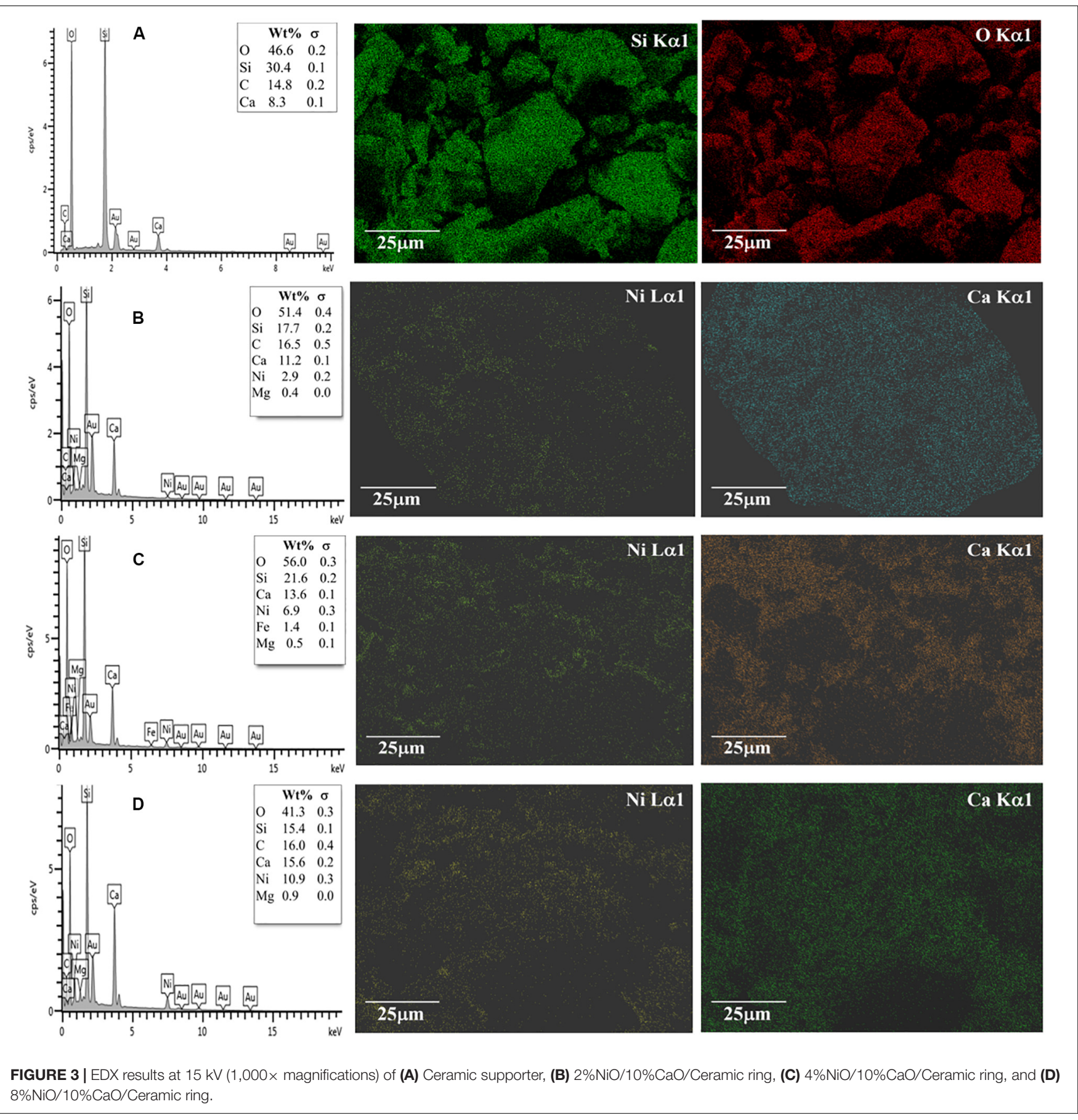

$60 \mathrm{~min}$, were used to analyze the concentrations of methane $\left(\mathrm{CH}_{4}\right)$ and carbon dioxide $\left(\mathrm{CO}_{2}\right)$ of the gas products to give the insight to understand the effect of the $\mathrm{NiO} / \mathrm{CaO}$ catalysts on the extended reactions involving the composition shifts of the syngas passing through the catalytic unit. The analyzed composition results of the syngas were summarized in Table 3.

Figure 7 illustrates the $\mathrm{CH}_{4}$ concentration of the syngas during the $60 \mathrm{~min}$ of processing time. As clearly seen from the graph, the presence of the catalysts in the extended unit noticeably affected the methane composition of the product gas. Increasing $\mathrm{NiO}$ dosages in the catalysts generally tended to result in increasing the $\mathrm{CH}_{4}$ concentration of the syngas. As the processing time evolved, the $\% \mathrm{CH}_{4}$ continuously increased to reach a maximum value to some extent of time, following by decreasing in the methane content to the end of the 1-h period. However, the observed $\% \mathrm{CH}_{4}$ from the system without the catalysts showed relatively low values and insignificant change throughout the process. The system attached to the catalytic unit packed with the catalyst having $8 \% \mathrm{NiO}$ gave the highest maximum $\mathrm{CH}_{4}$ composition value of 3.26 percent, followed 


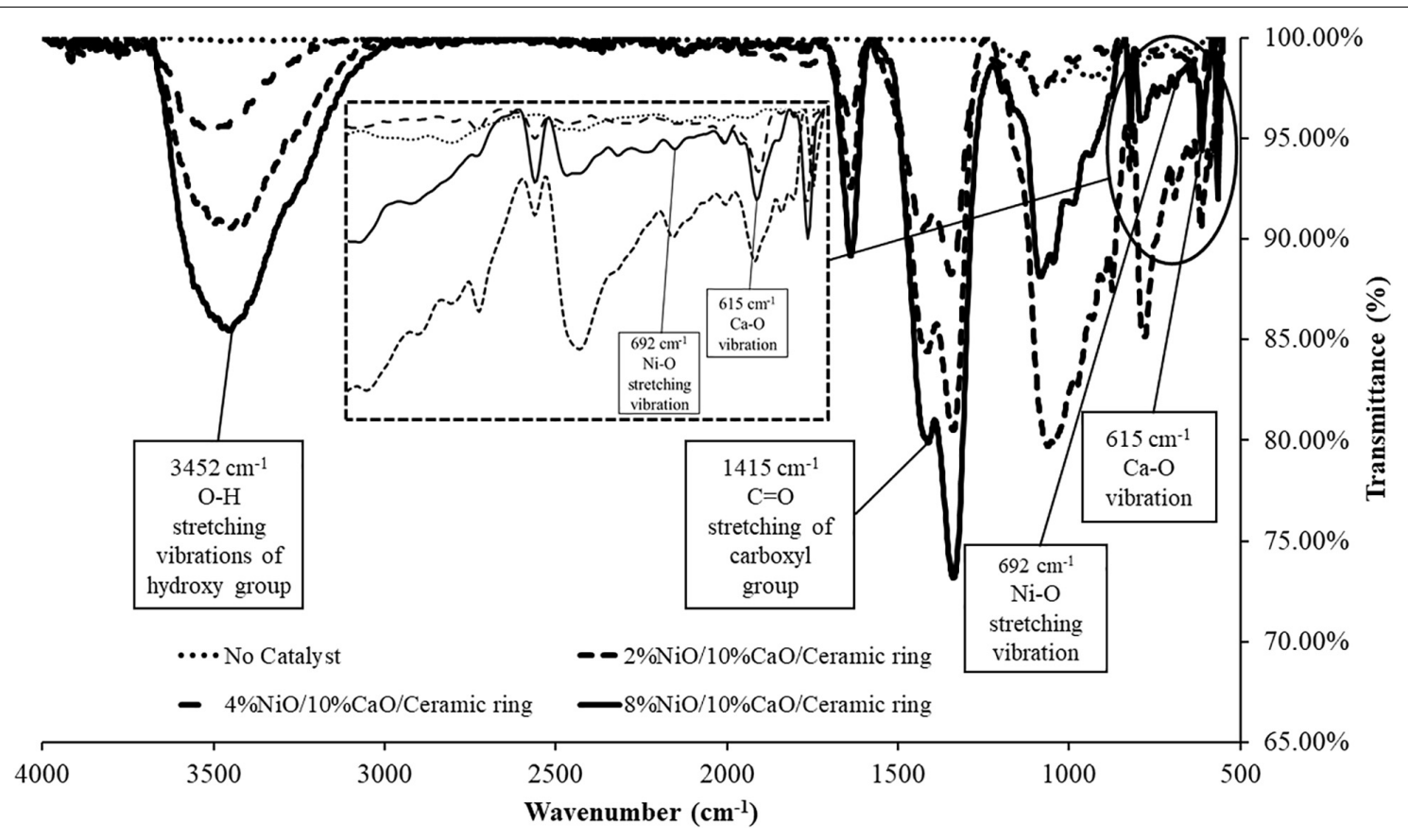

FIGURE 4 | FTIR analysis of Ceramic ring, 2\% NiO/10\%CaO/Ceramic ring, 4\% NiO/10\%CaO/Ceramic ring, and 8\% $\mathrm{NiO} / 10 \% \mathrm{CaO} / \mathrm{Ceramic}$ ring.

by those of the ones containing $4 \% \mathrm{NiO}$ at 2.32 percent, and $2 \% \mathrm{NiO}$ at 1.49 percent, respectively. The results were in good agreement with Phanpruk (2016) in which $\mathrm{NiO}$ was demonstrated to effectively improve the $\mathrm{CH}_{4}$ yields for the gasification process of palm residues. Figure 8 shows that the presence of the $\mathrm{NiO} / \mathrm{CaO}$ catalysts also affected the increased $\mathrm{CO}_{2}$ quantity in the collected gas samples in which a greater amount of $\mathrm{NiO}$ presented on the catalysts tended to yield higher $\mathrm{CO}_{2}$ content. With the proceeding time, the $\mathrm{CO}_{2}$ concentration gradually increased to reach a plateau with a slight decrease in $\mathrm{CO}_{2}$ content, particularly at a longer time near the end of the process. The above-mentioned results clearly indicated that the prepare $\mathrm{NiO} / \mathrm{CaO}$ catalysts enhanced the cracking of tar and of hydrocarbon compounds $\left(\mathrm{C}_{m} \mathrm{H}_{n}\right)$ in gaseous products. The NiO-based catalysts could probably facilitate the further chemical cracking reactions of the tar components with a high number of carbons presented in the hot gas that left from the gasifier. During the course of involving complex reactions, the large-molecule volatile $\operatorname{tar}\left(\mathrm{C}_{\mathrm{m}} \mathrm{H}_{\mathrm{n}}\right)$ would presumably react with the produced moisture particularly on the active surface of the catalyst, resulting in the formation of hydrocarbons with less carbon altogether with the $\mathrm{CO}_{2}$ and $\mathrm{H}_{2}$ by-products. Hence, the increase in $\mathrm{CH}_{4}$ and $\mathrm{CO}_{2}$ concentrations of the gas product were obtained. As observed in Figure 7, the $\mathrm{CH}_{4}$ concentrations decreased after reached the maximums, particularly at longer processing time (35, 45, $60 \mathrm{~min})$. The $\mathrm{CH}_{4}$ could possibly further react with the presence of $\mathrm{H}_{2} \mathrm{O}$ in the undergoing steam reforming reaction to some extent, resulting in improved $\mathrm{H}_{2}$ yield. At long processing time, the gasification would presumably reach the equilibrium. The $\mathrm{CO}_{2}$ could also react with the $\mathrm{H}_{2}$ in the reversible water-gas shift reaction, resulting in a decrease in $\mathrm{CO}_{2}$ concentration (as seen in Figure 8).

\section{Effect of Biochar on Tar Removal Enhancement}

A filter chamber packed with $1 \mathrm{~kg}$ of 50:50 (durian/mangosteen) biochar was connected right after the catalytic unit to trap the excess volatile tar compounds prior to the gas exit to improve the tar removal efficiency. Figure 9 shows the amount of adsorbed tar by the biochar presented in the filter unit after 60 min of the gasification process of $1 \mathrm{~kg}$ of kernels. To study the effect of the biochar as the effective adsorbent for tar adsorption, a baseline study was performed with the absence of the biochar in the filter chamber. The amount of adsorbed tar was calculated from the weight difference of the filter prior to and after the process. In most cases, a little amount of thin-film-like tar approximately $0.2 \mathrm{~kg}$ (per $1 \mathrm{~kg}$ of biomass) was condensed and coated onto the internal surface of the filter unit. From the chart, the system with the biochar filter exhibited improved tar removal capacity as the amount of adsorbed tar increased compared to the system without biochar. Without the presence of excess condensed liquid being observed in the filter unit, it apparently implied that the volatile tar compounds were trapped by the biochar mainly by adsorption mechanism. When comparing the results obtained from the system having different $\mathrm{NiO}$ contents in the catalyst being used, the amount of adsorbed tar tended to increase with the increasing $\mathrm{NiO}$ concentrations within the range of 2 to 9 times. The results were in good agreement with the study by Kuchonthara's study (Kuchonthara et al., 2009), in which the $\mathrm{NiO} / \mathrm{Al}_{2} \mathrm{O}_{3}$ catalysts were used to improve the 

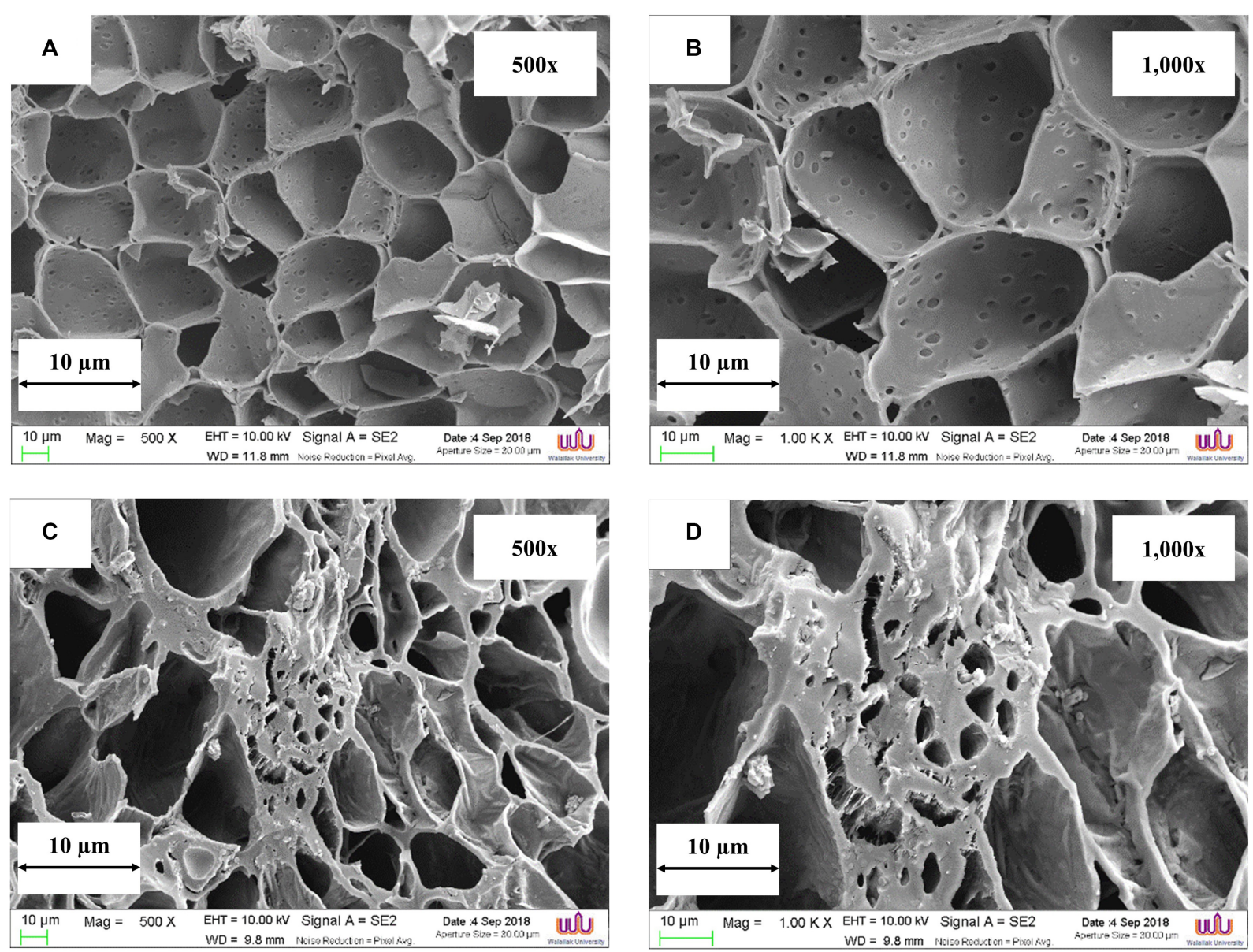

FIGURE 5 | SEM results at $10 \mathrm{kV}$ of (A) durian-peel biochar (500x magnification), (B) durian-peel biochar (1,000 $\times$ magnification), (C) mangosteen-peel biochar (500 $\times$ magnification), and (D) mangosteen-peel biochar (1,000 $\times$ magnification).
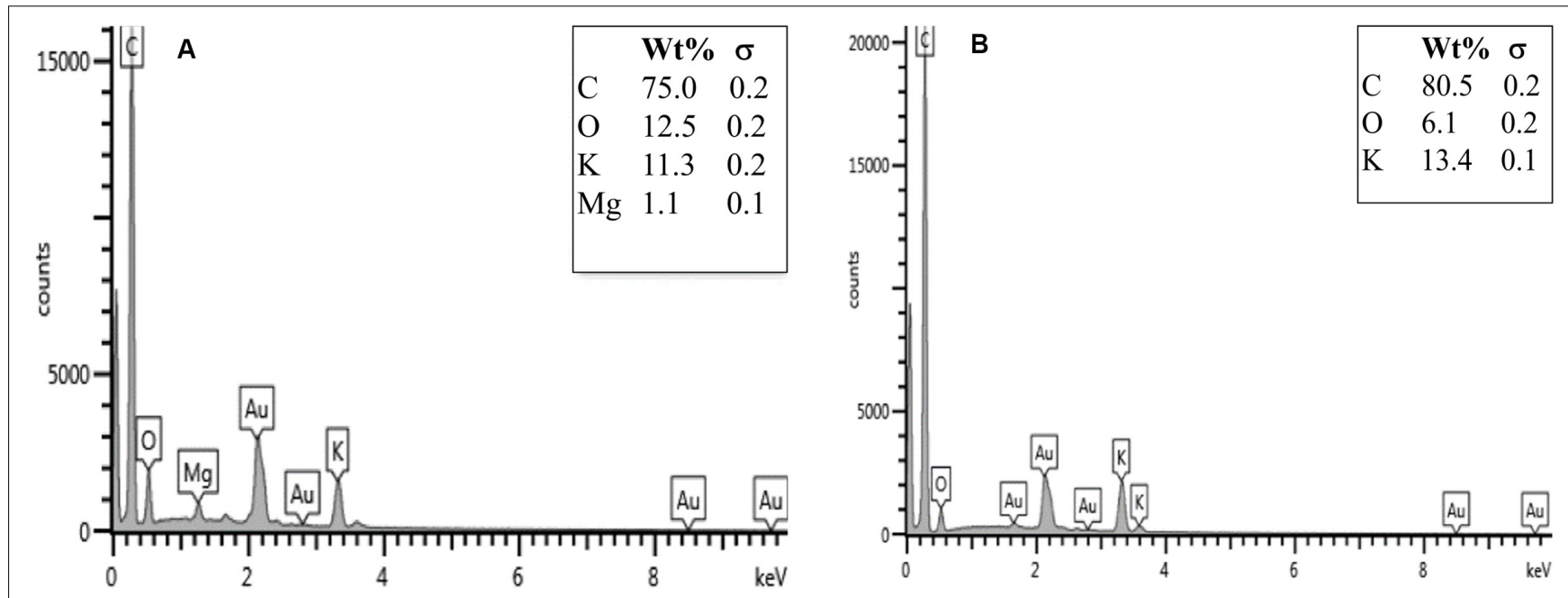

FIGURE 6 | EDX results at $10 \mathrm{kV}$ (500 × magnification) of (A) durian-peel biochar and (B) mangosteen-peel biochar. 
TABLE $3 \mid \mathrm{CH}_{4}$ and $\mathrm{CO}_{2}$ composition of syngas.

\begin{tabular}{|c|c|c|c|c|c|c|c|c|c|c|c|}
\hline \multirow[t]{2}{*}{ Sample } & \multicolumn{2}{|c|}{$15 \mathrm{~min}$} & \multicolumn{2}{|c|}{$25 \mathrm{~min}$} & \multicolumn{2}{|c|}{$35 \mathrm{~min}$} & \multicolumn{2}{|c|}{$45 \mathrm{~min}$} & \multicolumn{2}{|c|}{$60 \mathrm{~min}$} & \multirow[t]{2}{*}{ Color of flames } \\
\hline & $\mathrm{CH}_{4}(\% \mathrm{vol})$ & $\mathrm{CO}_{2}(\% \mathrm{vol})$ & $\mathrm{CH}_{4}(\% \mathrm{vol})$ & $\mathrm{CO}_{2}(\% \mathrm{vol})$ & $\mathrm{CH}_{4}(\% \mathrm{vol})$ & $\mathrm{CO}_{2}(\% \mathrm{vol})$ & $\mathrm{CH}_{4}(\% \mathrm{vol})$ & $\mathrm{CO}_{2}(\% \mathrm{vol})$ & $\mathrm{CH}_{4}(\% \mathrm{vol})$ & $\mathrm{CO}_{2}(\% \mathrm{vol})$ & \\
\hline No Catalyst & 0.09 & 2.29 & 0.10 & 3.32 & 0.15 & 4.30 & 0.19 & 5.36 & 0.13 & 4.85 & $\begin{array}{c}\text { Yellow to orange, } \\
\text { a lot of smoke }\end{array}$ \\
\hline $2 \% \mathrm{NiO} / 10 \% \mathrm{CaO}$ & 1.46 & 25.18 & 1.49 & 31.69 & 1.07 & 27.51 & 0.98 & 27.18 & 0.41 & 20.01 & $\begin{array}{l}\text { Light yellow, } \\
\text { some smoke }\end{array}$ \\
\hline $4 \% \mathrm{NiO} / 10 \% \mathrm{CaO}$ & 1.00 & 27.31 & 2.32 & 39.93 & 1.78 & 44.43 & 1.01 & 43.77 & 0.60 & 37.18 & $\begin{array}{l}\text { Light yellow, few } \\
\text { smoke }\end{array}$ \\
\hline $8 \% \mathrm{NiO} / 10 \% \mathrm{CaO}$ & 1.73 & 28.75 & 2.34 & 36.21 & 3.26 & 45.45 & 2.09 & 43.76 & 0.96 & 38.39 & $\begin{array}{l}\text { Light yellow with } \\
\text { outer light blue, } \\
\text { few smoke }\end{array}$ \\
\hline
\end{tabular}

catalytic reforming performance of the gasification process of rice husks that resulted in a significant tar reduction. When compared to the system with filter units filled with rice husks in Phanpruk's study (Phanpruk, 2016), it was found that the tar removal efficiency of the biochar filter was significantly improved by almost 100 percent. Since the tar components presented in the produced syngas left from the catalytic unit contained mostly volatile compounds in the gaseous state, a little amount of tar was be able to condense onto thin-film inside the surface of the filter unit. With biochar, those compounds were adsorbed and captured, compared to those without biochar. AS discussed earlier, further tar cracking could be facilitated by the presence of the catalysts in which large hydrocarbons were converted into chemical species smaller molecules with an appropriate size range to be adsorbed by the used biochar. Therefore, the amount of the captured tar was significantly increased with the increasing $\% \mathrm{NiO}$. As priorly discussed, the biochar prepared from the durian and mangosteen peels residues, having a porous structure with average pore size around 11.193 to $11.912 \mathrm{~nm}$, possessed relatively high specific surface area $\left(0.9219-0.9989 \mathrm{~m}^{2} / \mathrm{g}\right)$ which was capable of adsorbing tar molecules. A similar observation was also reported elsewhere (Phuphuakrat et al., 2010).

In this study, the color of the flames at the vent flare was also observed. Once the process started and reached the steady-state, the flare was lidded up to monitor the physical combustion of

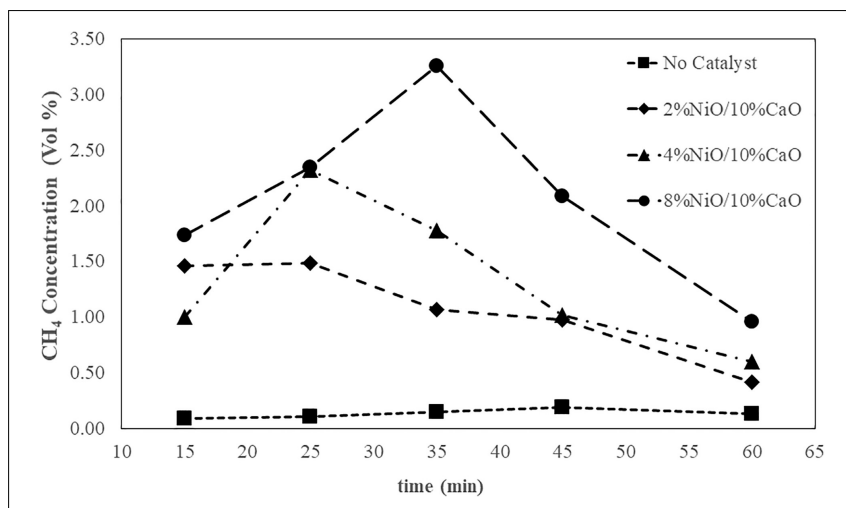

FIGURE 7 | $\mathrm{CH}_{4}$ concentration of syngas obtained from the gasification process at a fixed airflow rate of $25 \mathrm{~L} / \mathrm{min}$. the produced gas. Little fluctuations in the color shade of the lid flames throughout the process could be seen which was varying from light yellows with smoke to light blues with less smoke. The best flame appearance having a blue color with little smoke apparently occurred after the processing time had reached 25 to $35 \mathrm{~min}$ to the end of the process at $1 \mathrm{~h}$, indicating less amount of the left-over high MW tar compounds, and perhaps more

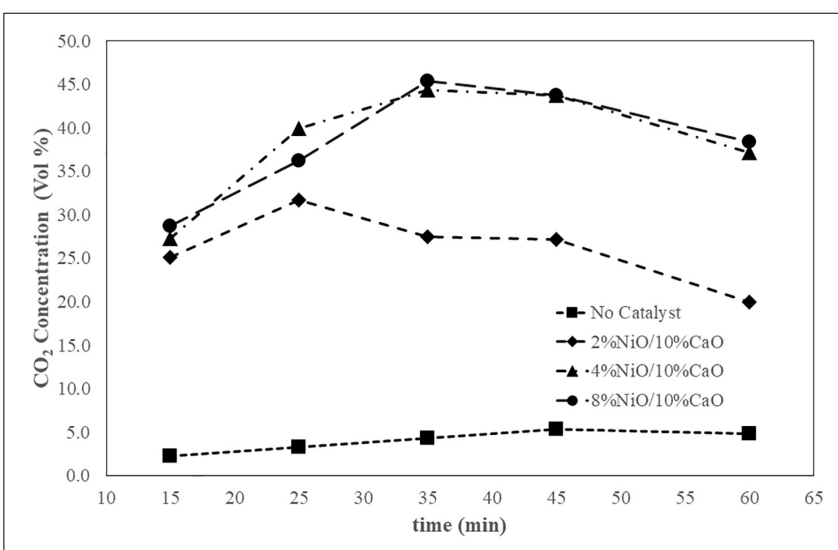

FIGURE 8 | $\mathrm{CO}_{2}$ concentration of syngas obtained from the gasification process at a fixed airflow rate of $25 \mathrm{~L} / \mathrm{min}$.

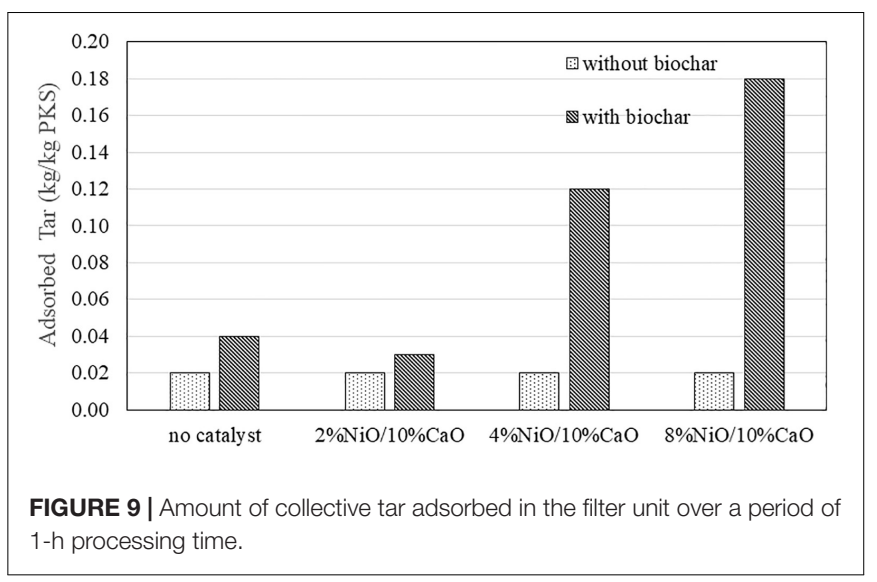


hydrogen or hydrocarbon gases with smaller molecules such as methane being presented.

\section{CONCLUSION}

The simple and economical air-gasification process, using palm kernel shells as the raw material with combined utilization of the catalyst and biochar adsorbent, was successfully demonstrated to produce low tar combustible syngas. In this study, the $\mathrm{NiO} / \mathrm{CaO}$ catalysts prepared from co-impregnation of $\mathrm{NiO}$ and $\mathrm{CaO}$ on the ceramic ring supporter having various $\mathrm{NiO}$ contents $(2,4,8 \mathrm{wt} \%)$ and a fixed $\mathrm{CaO}$ composition (10 wt\%) exhibited the capacity to facilitate the further tar cracking reactions of the hot gas leaving the gasifier. With increasing $\mathrm{NiO}$ amounts, the composition of the produced syngas tended to shift toward the increase in methane and carbon dioxide concentrations. At some extent of the undergoing reactions, the volatile tar components with large molecules were probably converted into small hydrocarbon $\mathrm{C}_{\mathrm{x}} \mathrm{H}_{\mathrm{y}}$ species (e.g., $\mathrm{CH}_{4}$ ) and other gaseous byproducts. The biochar prepared from mangosteen and durian peel residues also exhibited good performance in additional adsorbing the excess tar compounds presented in the syngas leaving the catalytic unit up to 9 times compared to the system with the absence of the biochar. The implication of the biochar utilization due to its promising adsorption performance would promote waste utilization of agricultural wastes by converting them into

\section{REFERENCES}

Ahmad, R., Hamidin, N., Md Ali, U., and Abidin, C. Z. A. (2014). Characterization of bio-oil from palm kernel shell pyrolysis. JMES 7, 1134-1140. doi: 10.15282/ jmes.7.2014.12.0110

Bonilla, J., Gordillo, G., and Cantor, C. (2019). Experimental gasification of coffee husk using pure oxygen-steam blends. Front. Energy Res. 7:127. doi: 10.3389/ fenrg.2019.00127

Brandt, P., Larsen, E., and Henriksen, U. (2000). High tar reduction in a two-stage gasifier. Energy Fuels 14, 816-819. doi: 10.1021/ef990182m

Chaichana, T., Waewsak, J., Kaew-on, J., and Onthong, U. (2014). Fuel properties of mangosteen pericarp charcoal. Thaksin Univ. J. 17, 29-36.

Chaiprasert, P., and Vitidsant, T. (2009). Effects of promoters on biomass gasification using nickel/dolomite catalyst. Korean J. Chem. Eng. 26, 1545-1549. doi: 10.1007/s11814-009-0259-7

Chiang, K.-Y., Chen, Y.-S., Tsai, W.-S., Lu, C.-H., and Chien, K.-L. (2012). Effect of calcium based catalyst on production of synthesis gas in gasification of waste bamboo chopsticks. Int. J. Hydrog. Energy 37, 13737-13745. doi: 10.1016/j. ijhydene.2012.03.042

Han, L., Wang, Q., Yang, Y., Yu, C., Fang, M., and Luo, Z. (2011). Hydrogen production via $\mathrm{CaO}$ sorption enhanced anaerobic gasification of sawdust in a bubbling fluidized bed. Int. J. Hydrog. Energy 36, 4820-4829. doi: 10.1016/j. ijhydene.2010.12.086

Ismail, K., Yarmo, M. A., Taufiq-Yap, Y. H., and Ahmad, A. (2012). The effect of particle size of $\mathrm{CaO}$ and $\mathrm{MgO}$ as catalysts for gasification of oil palm empty fruit bunch to produce hydrogen. Int. J. Hydrog. Energy 37, 3639-3644. doi: 10.1016/j.ijhydene.2011.05.100

Kimura, T., Miyazawa, T., Nishikawa, J., Kado, S., Okumura, K., Miyao, T., et al. (2006). Development of Ni catalysts for tar removal by steam gasification of biomass. Appl. Catal. B Environ. 68, 160-170. doi: 10.1016/j.apcatb.2006. 08.007

Koike, M., Ishikawa, C., Li, D., Wang, L., Nakagawa, Y., and Tomishige, K. (2013). Catalytic performance of manganese-promoted nickel catalysts for the steam high-value biochar products. It is likely that biochar prepared from other biomass residues would give similar adsorption performance in terms of improved tar reduction of syngas. This study is a part of the initiative to promote local implementation of renewable energy usages from biomass residues, particularly in southern Thailand where there are plentiful of unused resources.

\section{DATA AVAILABILITY STATEMENT}

All datasets presented in this study are included in the article/supplementary material.

\section{AUTHOR CONTRIBUTIONS}

$\mathrm{AK}$ and WD conceived the presented idea, supervised the findings, and analysis. SR performed the laboratory experiments. All authors discussed the results and contributed to the final manuscript.

\section{FUNDING}

The authors would like to acknowledge the financial support from Walailak University through the WU59113 research grant.

reforming of tar from biomass pyrolysis to synthesis gas. Fuel 103, 122-129. doi: 10.1016/j.fuel.2011.04.009

Kong, M., Fei, J., Wang, S., Lu, W., and Zheng, X. (2011). Influence of supports on catalytic behavior of nickel catalysts in carbon dioxide reforming of toluene as a model compound of tar from biomass gasification. Bioresour. Technol. 102, 2004-2008. doi: 10.1016/j.biortech.2010.09.054

Kostyniuk, A., Grilc, M., and Likozar, B. (2019). Catalytic cracking of biomassderived hydrocarbon tars or model compounds to form biobased Benzene. Toluene, and Xylene Isomer Mixtures. Indus. Eng. Chem. Res. 58, 7690-7705. doi: 10.1021/acs.iecr.9b01219

Kuchonthara, P., Kunsopa, S., Mekasut, L., and Vitidsant, T. (2009). Catalytic Reforming of Biomass-derived Tar using NiO/Al2O3 Modified by Base Oxides of $\mathrm{Mg}$ and $\mathrm{Ca}$. Master's thesis, Chulalongkorn University, Bangkok.

Lam, S. S., Tsang, Y. F., Yek, P. N. Y., Liew, R. K., Osman, M. S., Peng, W., et al. (2019). Co-processing of oil palm waste and waste oil via microwave cotorrefaction: a waste reduction approach for producing solid fuel product with improved properties. Process Saf. Environ. Protect. 128, 30-35. doi: 10.1016/j. psep.2019.05.034

Li, J., Liu, J., Liao, S., and Yan, R. (2010). Hydrogen-rich gas production by air-steam gasification of rice husk using supported nano-NiO/ $/ \gamma-\mathrm{Al} 2 \mathrm{O} 3$ catalyst. Int. J. Hydrog. Energy 35, 7399-7404. doi: 10.1016/j.ijhydene.2010. 04.108

McCaffrey, Z., Thy, P., Long, M., Oliveira, M., Wang, L., Torres, L., et al. (2019). Air and steam gasification of almond biomass. Front. Energy Res. 7:84. doi: 10.3389/fenrg.2019.00084

Mohammed, M. A. A., Salmiaton, A., Wan Azlina, W. A. K. G., Mohammad Amran, M. S., and Fakhru'l-Razi, A. (2011). Air gasification of empty fruit bunch for hydrogen-rich gas production in a fluidized-bed reactor. Energy Conv. Manag. 52, 1555-1561. doi: 10.1016/j.enconman.2010.10.023

Office of Agricultural Economics [OAE] (2019). Agricultural Statistics of Thailand [Online]. Bangkok: Office of Agricultural Economics.

Ogunkanmi, J. O., Kulla, D. M., Omisanya, N. O., Sumaila, M., Obada, D., and Dodoo Arhin, D. (2018). Extraction of bio-oil during pyrolysis of locally 
sourced palm kernel shells: effect of process parameters. Case Stud. Therm. Eng. 12, 711-716. doi: 10.1016/j.csite.2018.09.003

Okoroigwe, E., and Saffron, C. (2012). Determination of bioenergy potential of palm kernel shell by physicochemical characterization. Nigerian J. Technol. 31, 329-335.

Phanpruk, T. (2016). Gasification of Oil Palm using Downdraft Gasifier and Tar Removal by Catalyst. Master's thesis, Walailak University, Thai Buri.

Phanpruk, T., and Khamwichit, W. (2017). The estimate of energy generation potential of biomass residue from oil palm industries in Southern Thailand. J. Eng. Appl. Sci. 12, 2795-2801. doi: 10.3923/jeasci.2017.2795.2801

Phuphuakrat, T., Namioka, T., and Yoshikawa, K. (2010). Tar removal from biomass pyrolysis gas in two-step function of decomposition and adsorption. Appl. Energy 87, 2203-2211. doi: 10.1016/j.apenergy.2009.12.002

Rashidi, N. A., and Yusup, S. (2019). Production of palm kernel shell-based activated carbon by direct physical activation for carbon dioxide adsorption. Environ. Sci. Pollut. Res. 26, 33732-33746. doi: 10.1007/s11356-018-1903-8

Ravenni, G., Elhami, O. H., Ahrenfeldt, J., Henriksen, U. B., and Neubauer, Y. (2019). Adsorption and decomposition of tar model compounds over the surface of gasification char and active carbon within the temperature range 250-800 ${ }^{\circ}$ C. Appl. Energy 241, 139-151. doi: 10.1016/j.apenergy.2019.03.032

Samiran, N., Mohd Jaafar, M. N., Chong, C. T., and Jo-Han, N. (2015). A review of palm oil biomass as a feedstock for syngas fuel technology. J. Teknol. 72, 13-18. doi: $10.11113 /$ jt.v72.3932

Segawa, T., Kawaguchi, K., Ishii, K., Suzuki, M., Arimitsu, N., Yoshida, H., et al. (2015). Nickel oxide powder synthesis from aqueous solution of nickel nitrate hexahydrate by a microwave denitration method. Adv. Powder Technol. 26, 983-990. doi: 10.1016/j.apt.2015.04.004
Shahbaz, M., Suzana, Y., Inayat, A., Patrick, D., Partama, A., and Fadzil, A. (2016). Thermal Investigation of Palm Kernel Shell (PKS) with Coal Bottom Ash in Thermo Gravimetric Analyser (TGA) in Inert Atmosphere. Int. J. Biomass Renewables 5, 1-5.

Sutton, D., Kelleher, B., and Ross, J. R. H. (2001). Review of literature on catalysts for biomass gasification. Fuel Process. Technol. 73, 155-173. doi: 10.1016/S03783820(01)00208-9

Udomsirichakorn, J., Basu, P., Salam, P. A., and Acharya, B. (2013). Effect of $\mathrm{CaO}$ on tar reforming to hydrogen-enriched gas with in-process $\mathrm{CO} 2$ capture in a bubbling fluidized bed biomass steam gasifier. Int. J. Hydrog. Energy 38, 14495-14504. doi: 10.1016/j.ijhydene.2013.09.055

Wang, J., Cheng, G., You, Y., Xiao, B., Liu, S., He, P., et al. (2012). Hydrogen-rich gas production by steam gasification of municipal solid waste (MSW) using $\mathrm{NiO}$ supported on modified dolomite. Int. J. Hydrog. Energy 37, 6503-6510. doi: 10.1016/j.ijhydene.2012.01.070

Conflict of Interest: The authors declare that the research was conducted in the absence of any commercial or financial relationships that could be construed as a potential conflict of interest.

Copyright $\odot 2020$ Dechapanya, Rattanahirun and Khamwichit. This is an openaccess article distributed under the terms of the Creative Commons Attribution License (CC BY). The use, distribution or reproduction in other forums is permitted, provided the original author(s) and the copyright owner(s) are credited and that the original publication in this journal is cited, in accordance with accepted academic practice. No use, distribution or reproduction is permitted which does not comply with these terms. 